\title{
Correlation, regression and cluster analyses on yield attributes and popping characteristics of popcorn (Zea mays L. everta) in derived sa- vanna and rainforest agro-ecologies of Nigeria
}

\author{
Oloruntoba OLAKOJO ${ }^{1,2}$, Folusho BANKOLE ${ }^{1}$, Dotun OGUNNIYAN ${ }^{3}$
}

Received April 21, 2020; accepted July 21, 2021.

Delo je prispelo 12. aprila 2020, sprejeto 21. julija 2021

Correlation, regression and cluster analyses on yield attributes and popping characteristics of popcorn (Zea mays L. everta) in derived savanna and rainforest agro-ecologies of Nigeria

Abstract: Information on the genetic and agronomic relationship among the crop characters is important for the breeding programs. This study aimed at determining the relationship among grain yield, popping expansion and other agronomic characters in 19 popcorn lines evaluated in replicated trials at two locations. Correlation analysis was carried out to determine the relationship between agronomic traits while multiple stepwise regression analyses was used to determine the contribution of other agronomic traits to grain yield. Results showed that plant and ear heights as well as cob length exhibited positive and significant association with grain yield. Popping volume showed negative and significant association $\left(-0.45^{\star *}\right)$ with grain yield while 100 -grain mass had a negative and significant correlation $\left(-0.37^{\star *}\right)$ with popping volume. Stepwise multiple regression analysis showed that ear height, cob length, plant aspect and 100-grain mass contributed a total of $53.66 \%$ to variation in grain yield, with ear height contributing the highest portion (22.51\%). Cluster analysis grouped popcorn lines into four different clusters, where 'Small Pearl Shaped' and 'Popcorn 33-1-Y' belonged to cluster II and IV, respectively, showing how divergent they are and possible utilization for hybrid formation. Improvement for popcorn should focus on identifying lines with acceptable level of popping volume and improved on their grain yield and yield attributes.

Key words: correlation; qualitative traits; dendrogram; popcorn yield; popping volume; principal component; popcorn; morphology
Korelacijska, regresijska in klasterska analiza dejavnikov, ki vplivajo na pridelek in ekspanzijske lastnosti pokovke (Zea mays L. everta) v agroekosistemih prehodne savane in deževnega gozda Nigerije

Izvleček: Informacije o povezanosti genetskih in agronomskih lastnosti poljščin so pomembne za žlahtniteljske programe. Namen te raziskave je bil določiti povezavo med pridelkom zrnja, stopnjo ekspanzije in drugimi agronomskimi lastnostmi 19 linij pokovke, ovrednoteno v poskusih s ponovitvami na dveh lokacijah. Za določitev povezav med agronomskimi lastnostmi je bila uporabljena korelacijska anliza, za določitev prispevka posameznih agronomskih lastnosti na pridelek zrnja je bila uporabljena multipla postopna regresija. Rezultati so pokazali da so imeli višina rastlin, višina izraščanja storžev in dolžina storžev značilno pozitivno povezavo s pridelkom zrnja. Volumen ekspandiranih zrn je pokazal značilno negativno povezavo $\left(-0,45^{\star *}\right) \mathrm{s}$ pridelkom zrnja, masa 100 zrn je imela značilno negativno korelacijo $\left(-0,37^{* *}\right) z$ volumnom ekspandiranih zrn. Analiza s postopno multiplo regresijo je pokazala, da višina storža na rastlini, njegova dolžina, izgled rastline in masa 100 zrn prispevajo $53,66 \%$ variabilnosti v pridelku zrnja, pri čemer višina storža na rastlini prispeva največji delež $(22,51 \%)$. Klasterska analiza je združila linije pokovke $\mathrm{v}$ štiri različne grozde, kjer sta bili 'Small Pearl Shaped' in 'Popcorn 33-1-Y' uvrščeni v II in IV skupino, kar kaže na njuno veliko različnost in možnost uporabe pri tvorbi križancev. Izboljšave pri pokovki bi se morale osredotočiti na prepoznavanju linij s sprejemljivim volumnon ekspandiranih zrn in izboljšanim pridelkom zrnja ter izboljšanimi lastnostmi povezanimi s pridelkom.

Ključne besede: korelacija; kakovostne lastnosti; dendrogram; pridelek pokovke; volumen ekspadiranih zrn; glavna komponenta; pokovka; morfologija

1 Department of Agronomy, University of Ilorin, P.M.B. 1515, Ilorin, Nigeria

2 Corresponding author, e-mail: tobaolakojo@yahoo.com

3 Institute of Agricultural Research and Training, Obafemi Awolowo University, P.M.B. 5029, Moor Plantation, Ibadan, Nigeria 


\section{INTRODUCTION}

Success in improvement of grain yield and popping quality of popcorn requires the understanding of the nature of relationships between component traits that determine yield and other quantitative characters. Among the tools that provide such information are correlation and regression analyses. Correlation refers to the degree of measure of association between two characters or degree to which they vary among themselves (Mohanan, 2010). Association among characters can be measured in terms of direction (viz: positive or negative) and/or magnitude of the association. A positive correlation implies that improvement of one trait can lead to the improvement of the other trait through indirect selection while a negative correlation shows that improvement of one trait leads to the declination of another trait. This suggests that the knowledge of association of traits such as grain yield and/or popping expansion with other agronomic traits is very pertinent in putting together selection criteria or indices useful for popcorn (Zea mays L. everta) improvement.

Popcorn is cultivated for grain yield and popping quality and previous studies have shown that the two traits are negatively correlated. For example, the report of a study conducted by Vijayabharathi et al. (2009) revealed a positive association between popping expansion volume and popping expansion ratio, whereas the relationship between ear length and popping expansion ratio as well as between grain yield and popping expansion ratio was negative. In an earlier study, Dofing et al. (1991) had reported a negative association between volume expansion and yield components (such as ear length, ear diameter, 50-kernel mass), except for number of kernel rows/ear. The information obtained from these study implies that selection for large popping volume will result to reduction of grain yield and vice versa. Moradi and Azarpour (2011) as well as Sreckov et al. (2011) in separate studies also reported that grain yield was significantly and positively correlated with ear length, rows/ear, plant height and ear prolificacy.

While correlations provide information on the nature and magnitude of association between characters, regression analysis determines the significant level of contribution of each independent variable to the dependent variable, such as grain yield. Traits that contribute significantly to dependent variable help to justify the amount of variation observed in the dependent trait, thereby predicting the outcome of the trait. There are scanty information in literature on the grain yield and popping determinants of local popcorn types in Nigeria compared to field corn. However, study conducted by Alikhani et al. (2010) on sweet corn (Zea mays convar. saccharata Koern.) reported a significant contribution of 1000-grain mass and grain number per square meter to observed grain yield. Similarly, Zhang et al. (2013) reported that ear length, kernel row number, plant height and ear height contributed significantly to average grain yield in field corn. Consequently, studies targeted towards improving popcorn yield should focus on traits that contribute significantly to its yield.

Apart from gaining information on relationships among traits, it is also important to determine the extent of relationship among genotypes for the purpose of hybridization. The use of multivariate approach permits the evaluation of genetic material on a set of traits that combine multiple pieces of information in a way to select the most promising materials, considering the relative importance of the traits for the total existing variance (Cruz et al., 2014). Cluster analysis among other multivariate approaches shows a great deal in providing knowledge of genetic diversity between parents, aiming to identify the hybrid combinations with heterotic effect and high level of heterozygosity, and to identify duplicates in germplasm banks (Cruz et al., 2014). This technique assists breeders in identifying genotype combinations with good heterotic effect, thereby increasing the possibility of coming up with improved cultivars.

Popcorn is a popular and nutritious delicacy, which is primarily utilized for human consumption as freshly popped corn, snacks, confectioneries, biscuits and cornflakes (Iken, 1993). It can be found on almost all the streets, campuses and at cinemas in Nigeria, serving as main or additional source of income for youths and other stakeholders in popcorn industry. This shows the high level of popcorn consumption in Nigeria Popcorn is a consumed by people of different ages and status in Nigeria. Its production is however faced with poor popping expansion with low ratio of popped to unpopped and consequently poor economic return to the processors. The available varieties were also poor in grain yield per hectare with marginal profit to farmers, while some farmers completely abandoned it production because of these production challenges. Some processor therefore resort to buying exotic popcorn varieties with high exchange rate to further deplete the foreign reserve. Crop breeding as a matter of fact requires proper understanding of the agronomic traits of the crop as well as the interactions of the traits for yield. This study was therefore designed to determine (i) the nature of the relationship between grain yield, popping expansion and other agronomic characters, (ii) the percentage contribution of agronomic traits to grain yield in popcorn, and (iii) and the genetic diversity among the tested popcorn lines. This vital information will 
provide plant breeders with some selection criteria for breeding popcorn for good popping expansion, higher grain yield and consumer acceptability.

\section{MATERIALS AND METHODS}

The details of the genetic materials used for this study have been provided elsewhere (Olakojo et al., 2019). Briefly, the genetic materials comprised 19 popcorn lines that were collected from various part of southwestern Nigeria and improved for uniformity through intra-population selection prior to evaluation. A commercial variety (Eruwa Local), which is commonly grown by farmers, was used as a check variety as there are no released popcorn varieties in Nigeria so far. The study was conducted at the Institute of Agricultural Research and Training (IAR \& T), Moor Plantation, Ibadan (Latitude $3^{\circ} 50^{\prime} \mathrm{E}$ Longitude $7^{\circ} 22^{\prime} \mathrm{N}$ ) and IAR \& $\mathrm{T}$ Research Station at Ikenne, Ogun State, (Latitude $3^{\circ}$ 42 'E Longitude $6{ }^{\circ} 53^{\prime} \mathrm{N}$ ) representing derived savannah and rainforest agro-ecologies of Nigeria, respectively. The trial was laid out in a randomized complete block design with three replications. Each plot had two five-meter long rows. Two seeds were sown per hole at a spacing $75 \times 50 \mathrm{~cm}$ to give 44 stands per plot of $3 \times$ 5 meter square with an alley of one meter between one plot and the other to give a total experimental area of $17 \times 27 \mathrm{~m}$. A total of $180 \mathrm{~kg} \mathrm{ha}^{-1}$ of NPK 20:10:10 fertilizer was applied at three weeks after sowing (3 WAS) with $100 \mathrm{~kg} \mathrm{ha}^{-1}$ of urea six weeks after sowing (6 WAS). Weeds were chemically controlled with the application of pre-emergence herbicides ( $250 \mathrm{~g} \mathrm{l}^{-1}$ Metolachlor and $250 \mathrm{~g} \mathrm{l}^{-1}$ Atrazine a.i.) @ $51 \mathrm{ha}^{-1}$. Two supplementary hoeing were carried out 6 WAS and 10 WAS to reduce crop-weed competition.

Data on flowering, diseases, aspects and grain yield were taken on all the plants per plot while agronomic characters were recorded on five random plants per plot in each replication. The data on popping characters were taken after popcorn varieties from each replicate has been bulked. Data were collected on days- to- $50 \%$ tasseling and silking (recorded as the number of days from sowing to when $50 \%$ of the plants had emerged tassel and silks in a plot, respectively), plant and ear height $(\mathrm{cm})$ (measured as the distance $(\mathrm{cm})$ from the base of the plant to the first tassel branch (plant) and node bearing the upper leaf (ear)); plant aspect, ear aspect and, husk cover, using a 1-5 rating scale, where $1=$ excellent, $2=$ very good, $3=$ good, $4=$ fair and $5=$ poor, according to Badu-Apraku et al. (2012), cob length, cob width, number of rows/cob, number of kernels/row, moisture content was measured with the aid of a moisture meter at harvest, while grain yields were computed at the adjusted moisture content of $12.0 \%$ using the formula (Tandzi and Mutengwa, 2019):

$$
G Y=\frac{\text { Field mass } \times 10(100-\mathrm{MC}) \times 0.8}{(100-\text { Adjusted MC }) \times(5 \times 1.5)}
$$

Where $\mathrm{MC}=$ Moisture content $(\%) ; 0.8=$ shelling coefficient and the harvested area in $\mathrm{m}^{2}, \mathrm{GY}=$ Grain yield.

Diseases scored for includes streak (Maize streak virus), rust (Puccina polysora Underw.), blight (Bipolaris maydis (Y. Nisik. \& C. Miyake) Shoemaker), curvularia, using a rating of 1-5. Morphological data was also recorded at different stages of growth (seedling, vegetative and flowering stage). Stem color and broadness of leaves were recorded at the seedling stage; leaf color, color of mid-rib, color of leaf blade, leaf orientation at vegetative stage; color of anther, color of silk, nature of anthesis at flowering stage; cob shape, cob circumference, cob length, shape of the tip and kernel row arrangement at harvest while seed characters such as seed color, seed shape, number of seeds per row, number of rows per cob and presence or absence of awn were recorded at post-harvest stage by mere observation of the cobs.

Data collected were subjected to statistical analysis using Statistical Analysis System (SAS) version 9.3 (SAS institute, 2011) Pearson correlation and multiple stepwise regression analyses were carried out to determine the relationship between traits and contribution of other agronomic traits to grain yield, respectively. Principal Component Analysis (PCA) was also conducted to determine the contribution of each trait to variability in the performance of the popcorn lines. Cluster analysis was carried out using ward linkage dendrogram with the aid of Statistical Package for Social Science (SPSS) (IBM Corp, 2011).

\section{RESULTS AND DISCUSSION}

Morphological characteristics of the 19 popcorn lines are presented in Table 1. Results showed that stem color ranged from purple to brown while 'Popcorn 2-S' was the only variety with green stem color. This unique feature of 'Popcorn 2-S' for stem color suggests that this line is in a class of its own and this color uniqueness can serve as a distinguishing factor and as a morphological marker that differentiates it from other popcorn lines. Green leaf color was observed for most of the popcorn evaluated except for small pearl shaped and 'Popcorn 36-Y' which had light green leaf color. The dominating 
nature of green among the lines show the high level of chlorophyll content in them. The lines with light green leaf may possibly share the same parental line. Color of mid-rib ranged from light green to white. However, 'Popcorn 34-Y', 'Popcorn 4-Y' and 'Popcorn 52-Y' had green mid-rib color. With mid-rib color ranging between green, light green and white, the light green midrib colored materials are likely to have emanated from the combination between green and white. The leaf broadness of 'Popcorn 9-Y', 'Popcorn 20-Y', large pearl shaped, 'Popcorn 2-S ', 'Popcorn 37-Y' and 'Popcorn 33$1-\mathrm{Y}^{\prime}$ is desirable as its wide plant architecture in terms of area covered tend to reduce weed emergence by preventing light penetration into the soil. The wide canopy structure could also promote better assimilation of light during photosynthesis thereby increasing grain filling and consequently grain yield (Sun et al., 2019). Popcorn lines with fairly broad or narrow leaf as well as erect leaf orientation ('Popcorn44-Y' and large pearl shaped) are also desirable as they allow increase in plant population when planted sole. There will be less completion among plants since area covered by these lines of popcorn is minimal. Similarly, the characteristics suggest the lines suitable for better intercropping with other crops. Erect leaf orientation was observed in 'Popcorn 44-Y' and large pearl shaped while other lines were drooping. The color of anther ranged from green to light green while some of the varieties had purple dots on their green anther, which is an indication that it can be used to distinguish their respective popcorn lines from others. 'Popcorn $4-Y^{\prime}$ ' is unique among others with respect to silk color (cream), suggesting that this particular trait can be used as a morphological marker to identify this genotype during simple selection exercise, or to track the line when used in composite varietal development.

Most of the popcorn lines had primary-secondary branching anthesis, while few of them had only primary branching anthesis. Leaf blades of the popcorn lines were mostly green. However, 'Popcorn 44-Y', 'Popcorn 6-Y' and 'Popcorn 52-Y' had brown leaf blade while that of 'Eruwa' local was white.

Table 2 shows the morphological characteristics of cob and kernel of the 19 popcorn lines. Some of the popcorn lines had cylindrical cob shape while others were cylindrical-conical. 'Popcorn 9-Y' and 'Popcorn $3-Y^{\prime}$ in particular had conical shape. Conical shaped cob tends to have higher measure of cob width while cylindrical shaped cob gives lesser value of cob width. As earlier reported by Reddy et al. (2003), the degree of popping and reduced cob girth were the only criteria that could be used as selection criteria for improving popping expansion. It may therefore be safe to assume that lesser cob width proportionately give larger popping expansion. Popcorn breeders may therefore be guided by this phenomenon by selecting for cylindrical shaped cob for enhanced popping expansion. These cylindrical shaped popcorn varieties may be good sources of gene for higher popping expansion. Kernel row arrangement for most of the lines was either regular or straight. 'Popcorn 33-1-Y' and 'Popcorn 36-Y' however had an irregular arrangement of kernel row while 'Popcorn 66-Y' and 'Popcorn 37-Y' had a spiral kernel arrangement. 'Popcorn 3-Y' had a strongly pointed kernel shape compared to other popcorn lines with either pointed or round shape, showing its distinctiveness with respect to this trait. The presence of awn on the kernels of all the popcorn suggests that they are closer to the wild type than the domesticated type and they tend to be resistant to many popcorn pests, and can be utilized as source of resistant gene for future breeding effort towards resistance to prevalent popcorn pest especially maize weevil. The deep yellow color observed on the kernels of some of the popcorn lines suggests that they have more number of complementary genes controlling them than those with light yellow coloration. During popping, the flakes are likely to assume the natural color of the kernel, therefore the use of artificial coloring during popping to make it appealing to children by some popcorn processors and sellers may not be necessary.

Pearson correlation coefficients of grain yield and other characters are presented in Table 3. Plant heights $\left(0.41^{\star *}\right)$ and ear heights $\left(0.42^{\star *}\right)$ as well as cob length $\left(0.36^{\star *}\right)$ correlated positively and significantly with grain yield which suggests a strong and positive relationship among these traits probably the two traits are being controlled by the same gene. This may be as a result of linkage or pleiotropy, indicating that an improvement in any of these traits could lead to an improvement in grain yield and vice versa. This invariably focuses on the importance of ear placement as one of the selection criteria for popcorn yield improvement. Hence, ear height and cob length may be considered necessary as traits to be looked out for in any popcorn improvement program relating to grain yield. This observation agrees with previous reports of Gautam et al. (1999) and Singh et al. (2006). However, the association between plant aspect and grain yield, as well as husk cover and grain yield were negative and significant $(\rho$ $\leq 0.05$ ). Therefore lower rating for husk cover and plant aspect on the field is important for enhanced yield. Loose husk cover predisposes popcorn ears to invasion of bird pests as they find it easy to peck on it because of its small kernel nature. The results further showed thatcob width and 100-grain mass were negatively cor- 


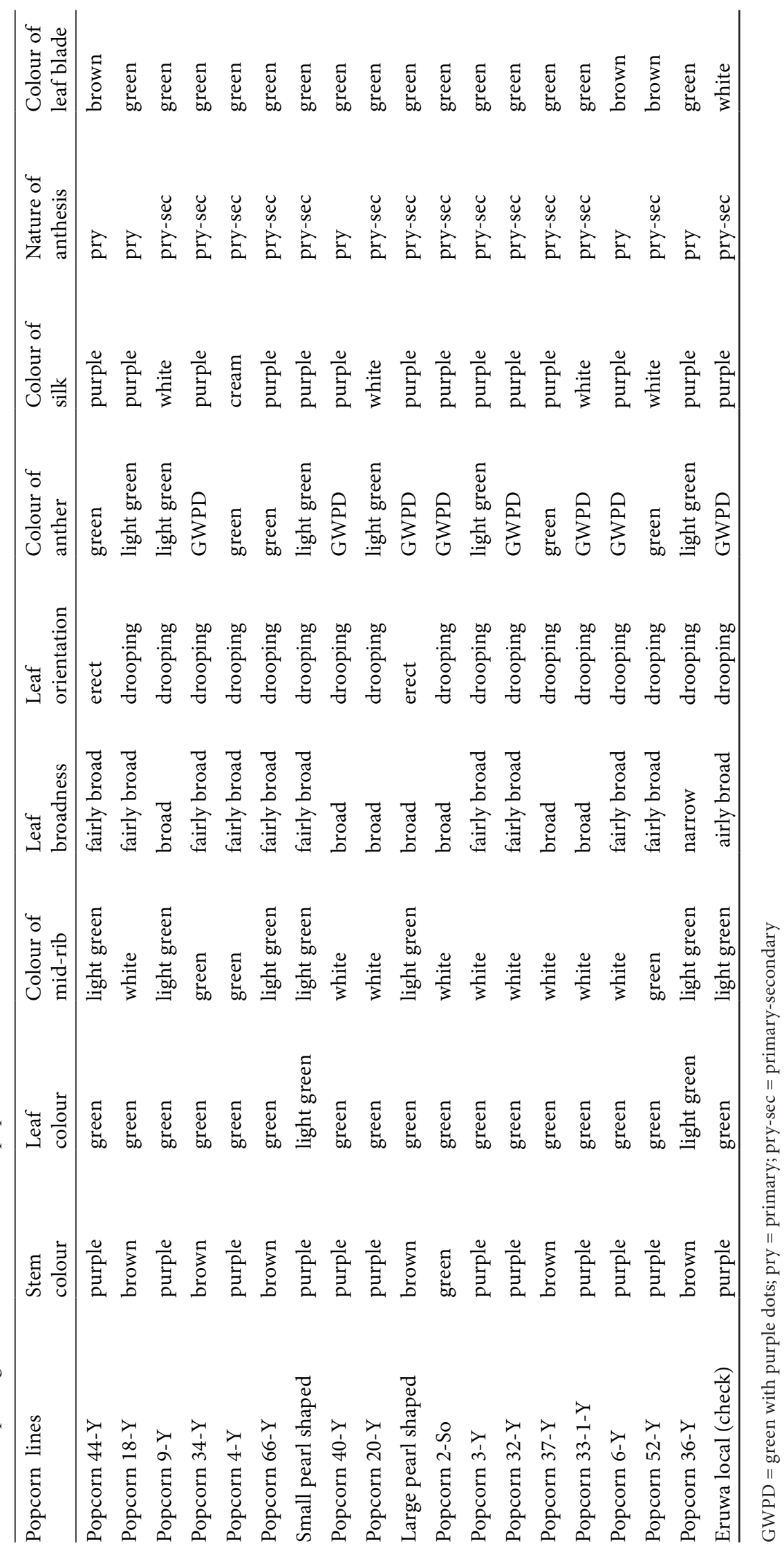


Table 2: Morphological characteristics of cob and kernel of 19 popcorn lines

\begin{tabular}{|c|c|c|c|c|c|c|}
\hline Popcorn lines & Cob shape & $\begin{array}{l}\text { Shape of } \\
\text { cob tip }\end{array}$ & $\begin{array}{l}\text { Kernel row } \\
\text { arrangement }\end{array}$ & Kernel shape & Presence of awn & Kernel colour \\
\hline Popcorn 44-Y & cylindrical & normal & regular & round & + & deep-y \\
\hline Popcorn 18-Y & cylindrical & curved & regular & pointed & + & light-y \\
\hline Popcorn 9-Y & conical & normal & regular & round & + & deep-y \\
\hline Popcorn 34-Y & cyl-conical & normal & straight & round & + & deep-y \\
\hline Popcorn 4-Y & cylindrical & normal & regular & round & + & deep-y \\
\hline Popcorn 66-Y & cylindrical & normal & spiral & round & + & light-y \\
\hline Small pearl shaped & cylindrical & normal & straight & pointed & + & deep-y \\
\hline Popcorn 40-Y & cyl-conical & normal & straight & round & + & light-y \\
\hline Popcorn 20-Y & cyl-conical & normal & straight & round & + & light-y \\
\hline Large pearl shaped & cylindrical & normal & regular & round & + & light-y \\
\hline Popcorn 2-So & cyl-conical & normal & regular & round & + & deep-y \\
\hline Popcorn 3-Y & conical & curved & regular & strongly pointed & + & light-y \\
\hline Popcorn 32-Y & cyl-conical & curved & straight & pointed & + & deep-y \\
\hline Popcorn 37-Y & cylindrical & curved & spiral & pointed & + & deep-y \\
\hline Popcorn 33-1-Y & cylindrical & normal & irregular & round & + & light-y \\
\hline Popcorn 6-Y & cylindrical & curved & straight & pointed & + & light-y \\
\hline Popcorn 52-Y & cylindrical & curved & regular & pointed & + & light-y \\
\hline Popcorn 36-Y & cylindrical & normal & irregular & round & + & light-y \\
\hline Eruwa local (check) & cyl-conical & normal & straight & pointed & + & light-y \\
\hline
\end{tabular}

Cyl-conical - cylindrical-conical + = awn was present; Light-Y = light yellow; Deep-Y = deep yellow

related with popping volume suggesting that these pairs of variables cannot be improved simultaneously. This implies that larger kernels will likely have a reduced popping volume. Small size of grain will bring about large number per mass thereby giving higher popping expansion by volume, knowing fully well that expansion is by volume while increased number of kernels will enhance the mass. Hence, popcorn breeders focusing on enlarged popping volume should select smaller kernels to boost the expansion of popcorn flakes. Guatam et al. (1999) also reported negative and significant correlation between 1000-kernel mass and popping expansion. Findings of Reddy et al. (2003) equally revealed that degree of popping and lesser cob girth were the only criteria which could be used as selection indices for improving popping expansion. Therefore, improvement of popping volume will be effective if selection is based on popcorn individuals with lesser cob width and kernel size. Grain yield on the other hand had a negative but significant association with popping volume. The negative correlation between grain yield and popping volume has been reported by several authors in previous studies (Dofing et al., 1991; Burak and Broccoli, 2001; Vijayabharathi et al., 2009; Rangel et al., 2011).
This seems to be one of the major problems in popcorn improvement as these two traits appear to be of great importance in popcorn industry. However, large popping volume is desirable by all stakeholders in popcorn industry being the end-product trait to be reckoned with. Popping expansion of popcorn should therefore be considered as a primary trait and associating traits should be focused on during selection exercise.

Stepwise multiple regression analyses for grain yield indicating the contribution of component traits to popcorn grain yield is shown in Table 4 . The results showed that ear height, cob length, plant aspect and 100 -grain mass contributed a total of $53.66 \%$ to grain yield, with ear height contributing the highest portion $(22.51 \%)$, followed by $17 \%$ contribution by cob length and $10.17 \%$ contribution by plant aspect while 100 -grain mass contributed the least portion (3.98\%). The results further explain the level of significance observed in these contributions, which in all cases were at 0.01 level of probability.

$$
Y i=a+b X_{1}+e \mathrm{i}
$$




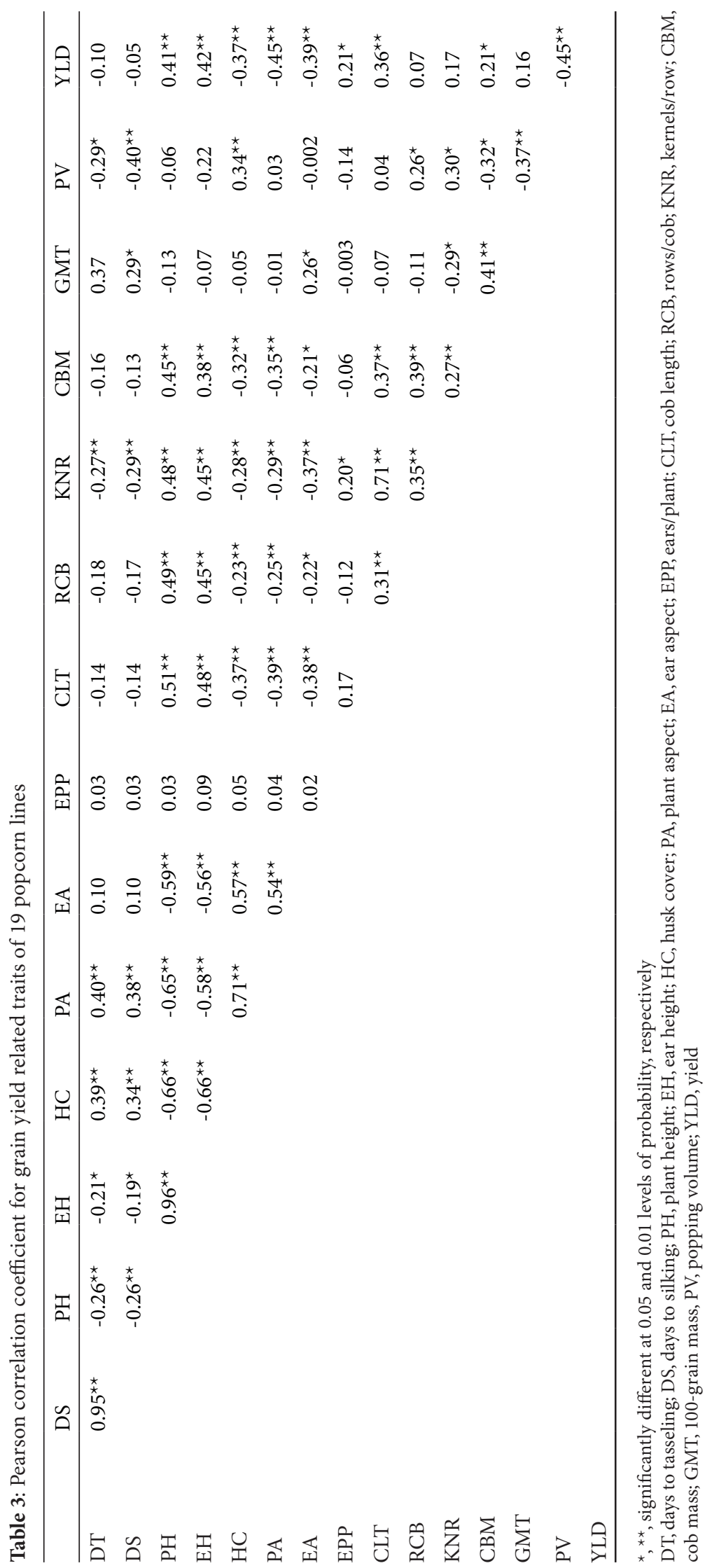


Where $Y i$ is the mean measurement of the dependent variable (Grain yield), $X i$ is the measurement of the independent variables, $b$ is the slope of regression line of $Y i$ on $X i$, a is the value of $\mathrm{Y}$ when $\mathrm{X}=0$ and $e i$ is the error associated with the $Y i$.

Principal Component Analysis (PCA) identifies the characters that contribute most to the variation within a group of entries (Ogunbodede, 1997). PCA data generated 21 components axes with eigen values ranging from 0.00-3.73, and components with above $9 \%$ proportion of variance were retained The first four principal components cumulatively accounted for about $55 \%$ of total variation (Table 5), while the first principal component (PC1) contributed approximately $20 \%$ of observed variation which was associated with popping volume, grain yield, 100-grain mass and husk cover. The second principal component (PC2) contributed about $16 \%$ of the variation and was associated with plant height, ear height, grain yield, days to tasseling and silking, cob length and kernels/row. The third principal component (PC3) on the other hand contributed about $11 \%$ of the variation which are linked to cob length, kernels/row, rows/cob, streak, ears per plant and plant height while the fourth principal component (PC4) contributed about $9 \%$ of the observed variation and was associated with ear aspect, husk cover, cob width and 100-grain mass. PCA can be estimated from the contribution of different variables to each principal component according to the Eigen vectors (Lezzoni and Pritts, 1991). Therefore, it is considered that the characters grouped into each of the components are associated in one way or the other and are governed by the same type of gene action. Consequently, characters with high loading value within the first four principal components such as ear aspect, cob width, popping volume and cob length are of high relevance and should be considered for selection in improvement program of popcorn.

Cluster analysis refers to a group of multivariate techniques which group individuals or objects with respect to the characters they possess, such that individuals with similar descriptions are gathered into the same cluster (Hair et al., 1995). In this study, popcorn lines in cluster I (popcorn '34-Y' to popcorn '32-Y') are grouped together on the basis of their similarities which can be traced ( Olakojo et al., 2019) to some attributes such as medium cob length, grain filling potential (number of kernels/row), tallness of the plant and early maturity. The second cluster comprising of 6 popcorn lines (small pearl shaped - popcorn 20-Y) are mostly low

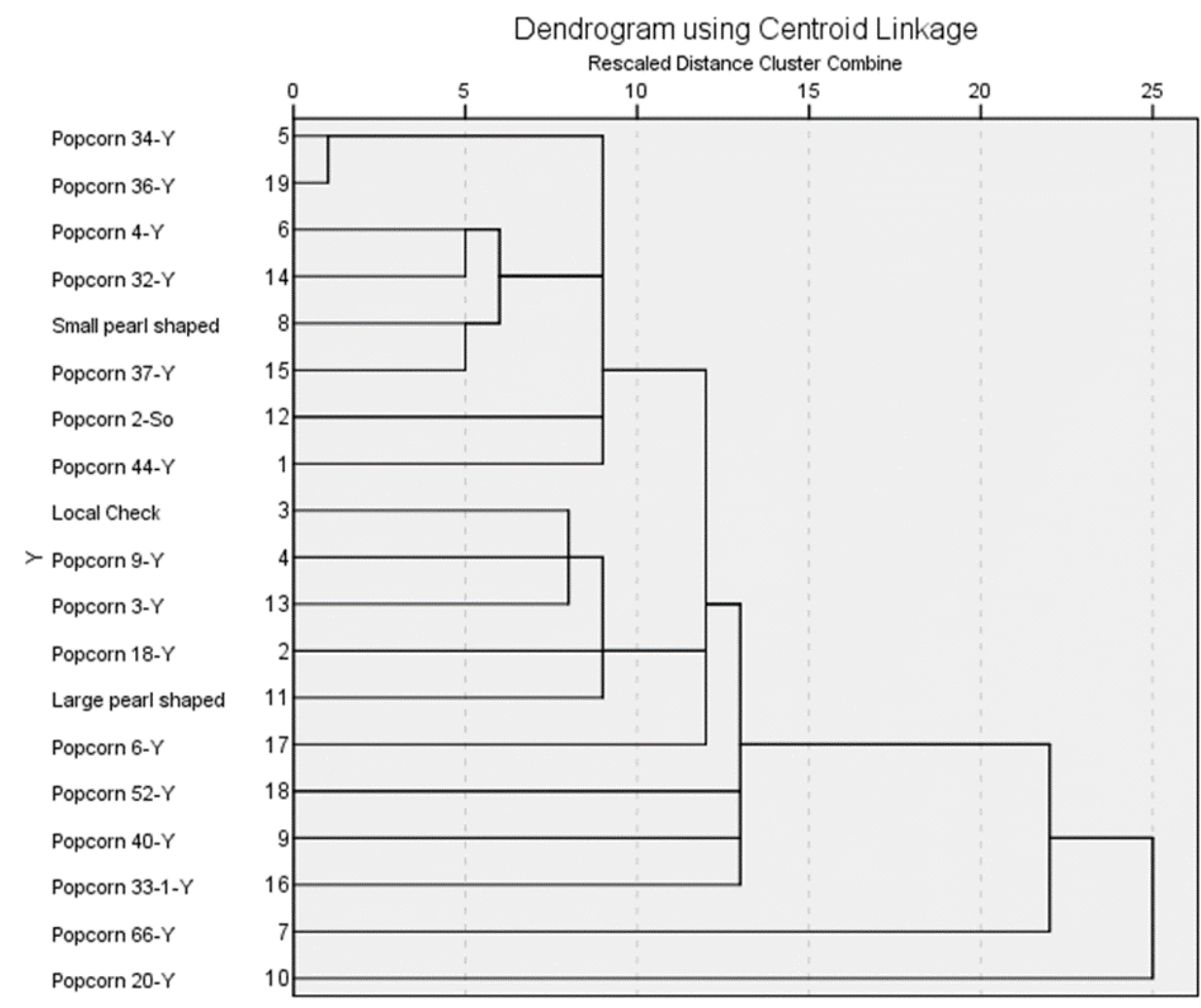

Figure 1: Dendrogram of relationship among 19 popcorn lines 
Table 4: Summary of Stepwise multiple regression for grain yield in 19 popcorn lines

\begin{tabular}{llll}
\hline Characters & Partial R & \% contribution to yield & F-value \\
\hline Ear height & 0.2251 & 22.51 & $15.97^{\star *}$ \\
Cob length & 0.1700 & 17.00 & $15.17^{\star *}$ \\
Plant aspect & 0.1017 & 10.17 & $10.72^{\star *}$ \\
100 - grain mass & 0.0398 & 3.98 & $4.46^{\star}$ \\
\hline
\end{tabular}

*, ** significantly different at 0.05 and 0.01 levels of probability, respectively

Table 5: Eigen values and vectors of observed characters in 19 Popcorn lines and their PCA values

\begin{tabular}{|c|c|c|c|c|}
\hline Characters & PC1 & PC2 & PC3 & PC4 \\
\hline Days to tasseling & -0.244 & -0.277 & -0.038 & -0.231 \\
\hline Days to silking & -0.274 & -0.284 & -0.064 & -0.201 \\
\hline Plant height & -0.127 & 0.360 & -0.263 & 0.142 \\
\hline Ear height & -0.225 & 0.347 & -0.135 & -0.056 \\
\hline Husk cover & 0.265 & -0.045 & 0.059 & 0.401 \\
\hline Plant aspect & 0.114 & -0.255 & 0.201 & -0.097 \\
\hline Ear aspect & 0.015 & -0.218 & -0.048 & 0.510 \\
\hline Ear per plant & -0.075 & 0.186 & 0.363 & 0.113 \\
\hline Streak & 0.144 & -0.253 & 0.374 & 0.153 \\
\hline Rust & 0.188 & -0.138 & -0.023 & -0.018 \\
\hline Blight & 0.00 & 0.00 & 0.00 & 0.00 \\
\hline Curvularia & 0.00 & 0.00 & 0.00 & 0.00 \\
\hline Army worm & 0.051 & 0.162 & -0.117 & 0.018 \\
\hline Cob length & 0.029 & 0.290 & 0.440 & 0.156 \\
\hline Rows/cob & 0.135 & -0.004 & -0.378 & 0.200 \\
\hline Kernels/row & 0.201 & 0.257 & 0.402 & -0.019 \\
\hline Cob width & -0.194 & -0.092 & -0.149 & 0.489 \\
\hline 100-Grain mass & -0.248 & -0.245 & 0.112 & 0.299 \\
\hline Popping volume & 0.450 & 0.056 & -0.101 & -0.041 \\
\hline Grain Yield & -0.295 & 0.330 & 0.149 & 0.142 \\
\hline Eigen values & 3.732 & 3.073 & 1.996 & 1.728 \\
\hline$\%$ Variance & 19.64 & 16.17 & 10.50 & 9.09 \\
\hline$\%$ cumulative & 19.64 & 35.81 & 46.32 & 55.41 \\
\hline
\end{tabular}

streak (maize streak virus), rust (Puccina polysora), blight (Bipolaris maydis), curvularia, army worm (Spodoptera frugiperda)

yielding with short height, short cob length and has good popping potential. The 5 lines grouped together in cluster III have the measure of only 100-grain mass in common but closely associated with those in cluster IV with respect to this attribute (100-grain mass). Other attributes found to be similar among the 3 popcorn lines in cluster IV are long cob length, high yield and low popping volume. This confirms the strong relationship that existed between cob length and grain yield and also affirm the contribution of cob length to grain yield among the popcorn lines used in this study. This trait may be considered for yield improvement in popcorn breeding. Moreover, with cluster IV having low popping volume but high yield; it is at par with the 
result presented in Table 3, which shows the negative association between grain yield and popping volume of the lines.

Popcorn lines grouped within the same cluster are expected to exhibit high internal homogeneity while those between clusters are to exhibit high external heterogeneity. Therefore, each cluster in the dendrogram can be considered as a heterotic group. In other words, crosses made between inbred population developed from lines in cluster II (such as small pearl shaped) and that of cluster IV (such as popcorn '33-1-Y') may likely give high heterosis leading to the development of commercial $\mathrm{F}_{1}$ hybrids for the popcorn industry.

\section{CONCLUSION}

Ear height and cob length have demonstrated a great deal in affecting grain yield of the evaluated popcorn lines. They also contribute significantly to grain yield of popcorn. These traits no doubt should be of high consideration as selection criteria for the improvement of popcorn yield. The observed (positive) relationships among these traits will enable simultaneous improvement of these characters, thus saving time and resources. Similarly, lesser grain mass should be the target during improvement for popping expansion. Different heterotic group where the highest yielding popcorn and largest popping popcorn lines belong is an indication of the potential value of these materials for future breeding plans especially for hybrid development.

\section{ACKNOWLEDGEMENT}

The authors acknowledge the staff of Maize Improvement Programme at Institute of Agricultural Research and Training (IAR\&T) for assisting with field work and data collection at both testing sites.

\section{REFERENCES}

Alikhani, M.A., Khazaei, F., Yari, L. and Khandan, A. (2010). Study on the correlation, regression and path coefficient analysis in sweet corn (Zea mays var. saccharata) under different levels of plant density and nitrogen rate. ARPN Journal of Agricultural and Biological Science, 5(6), 14-19.

Badu-Apraku, B., Fakorede, M.A.B., Menkir, A. and Sanogo, D. (editors). (2012). Conduct and Management of Maize Field Trials. IITA, Ibadan, Nigeria. 59p.

Burak, R. and Broccoli, A. M. (2001). Genetic and environmental correlations between yield comonents and pop- ping expansion in popcorn hybrids. Maize Genetics Cooperation Newsletter, 75, 38-40.

Cruz, C.D., Carneiro, P.C.S. and Regazzi, A.J. (2014). Modelos biométricos aplicados aomelhoramento genético. 3rd edn. Ed. UFV, Viçosa.

Dofing, S.M., Croz-Mason, N.D. and Compton, M.A.T. (1991). Inheritance of expansion volume and yield in two popcorn x dent corn crosses. Crop Science, 31, 715-718. https://doi.org/10.2135/cropsci1991.0011183X00310003003 $5 \mathrm{x}$

Gautam, A.S., Mittal, R.K and Bhandari, J.C. (1999). Correlations and path analysis in popcorn. Annals of Biology (Hissar) 15(2), 196.

Hair, J. R., Anderson, R. E., Tatham, R. L. and Black, W. C. (1995). Multivariate data analysis with readings. $4^{\text {th }}$ edition, Prentice-Hall, Englewood cliffs, NJ.

IBM Crop, Releases (2011). IBM SPSS Statistics for Windows, version 20.0. Armonk, NY: IBM Corp.

Iken, J.E. (1993). Popcorn production and utilization. In Fakorede, M.A., Alofe, O.O. and Kim, S.K. (eds). Maize Improvement Production and Utilization in Nigeria.

Lezzoni, A.F. and Pritts, M.P. (1991). Application of principal component analysis to horticultural research. Horticultural Science, 26(4), 334-338. https://doi.org/10.21273/ HORTSCI.26.4.334

Mohanan, K. (2010). Essentials of Plant Breeding PHI Learning Private. Ltd. New Delhi.

Moradi, M. and Azarpour E. (2011). Determination of most important part of yield components by path analysis in corn. Journal of American Science, 7, 134-147.

Ogunbodede, B.A. (1997). Multivariate analysis of genetic diversity in kenaf (Hibiscus cannabinus L.). African Crops Science Journal, 5(2), 127-133. https://doi.org/10.4314/ acsj.v5i2.27855

Olakojo, O.O., Olaoye, G., Akintunde, A.T. (2019). Performance of popcorn introductions for agronomic characters, grain yield and popping qualities in the forest and derived savannah agro-ecologies of Nigeria. Acta agriculturae Slovenica, 114(1), 53-60. https://doi.org/10.14720/ aas.2019.114.1.6

Rangel, R.M., Junior, A.T.A and Junior, S.P.F. (2011). Association between agronomical traits and popping expansion in a popcorn population under recurrent selection. Cienciae agrotechnologia, 35(2), 225-233. https://doi. org/10.1590/S1413-70542011000200001

Reddy, V.S., Mohan, Y. C., Rao, N.V and Krishna, L. (2003). Character association and path analysis in popcorn (Zea mays var. everta). Crop research, 25(2), 297-300.

Rupak, K., Verma and Singh, T.P. (1979). Interrelations among certain quantitative traits in popcorn. The Mysore Journal of Agricultural Science, 13, 15-18.

SAS Institute (2009). SAS system for Windows v. 9.3. SAS Inst. Inc., Cary, NC.

Singh, H., Chawla J. and Grewa, M. (2006). Correlation and path coefficient analysis on some elite maize genotypes. Crop Improvement, 33, 31-33.

Sun, J., Gao, J., Wang, Z., Hu, S., Zhang, F., Bao, H. and Fan Y. (2019). Maize canopy photosynthetic efficiency, plant 
growth, and yield responses to tillage depth. Agronomy, 9(3), 1-18. https://doi.org/10.3390/agronomy9010003

Sreckov, Z., Nastasic A., Bocanski J., Djalovic I., Vukosavljev M. and Jockovic B. (2011). Correlation and path analysis of grain yield and morphological traits in test-cross populations of maize. Pakistan Journal of Botany, 43, 1729-1731.

Tandzi, N. L. and Mutengwa, C. (2019). Estimation of maize (Zea mays L.) yield per harvest area: appropriate methods. Agronomy. https://doi.org/10.3390/agronomy10010029
Vijayabharathi, A., Anandakumar, C.R. and Gnanamalar, R.P. (2009). Combining ability analysis for yield and its components in popcorn (Zea mays var. everta Sturt.). Electronic Journal of Plant Breeding, 1, 28-32.

Zhang, H., Wang, X., He, D. and Shui, H. (2013). Regression and correlation analysis between high-yield stability and main agronomic traits in maize. Journal of Southern Agriculture, 44(10), 1625-1628. 